\title{
Evaluation of Medico-Legal Cases in the Pediatric Emergency Department
}

\section{Çocuk Acil Servisine Başvuran Adli Olguların Değerlendirilmesi}

\author{
Ramiz Coşkun GÜNDÜZ¹, Halit HALIL ${ }^{2}$, Cemile DEMIREL AÇIKALIN¹, Cüneyt GÜRSOY ${ }^{1}$, Funda KURT², \\ Şanlıay ŞAHIN ${ }^{1}$, Atilla ÇiFCli ${ }^{1}$, Seher ÖZGÜN³
}

\begin{abstract}
${ }^{1}$ Ankara Child Health and Diseases Hematology Oncology Education and Research Hospital, Ankara, Turkey 2Zekai Tahir Burak Women's Health Education and Research Hospital, Ankara, Turkey

${ }^{3}$ Ankara Child Health and Diseases Hematology Oncology Education and Research Hospital, Children's Emergency Department, Ankara, Turkey
\end{abstract}

\begin{abstract}
Objective: Pediatric medico-legal events are important public health problems in the pediatric emergency service. They are considered among the leading causes of pediatric disabilities and deaths. We performed a study to evaluate the demographic features of the medico-legal cases who presented to our pediatric emergency service.

Material and Methods: During the 2-years study period, a total of 1586 patients presented to our service and were treated as medico-legal cases. Information about the patients was obtained from hospital records and analysed by the medical staff of the pediatric emergency service.

Results: 671 male (42.3\%) and 915 female (57.7\%) patients were included in our study. The majority of the patients were between $11-14$ years of age $(n=397 ; 25.0 \%)$. Drug intake was the major complaint $(n=827 ; 52.1 \%)$ of our patients. Winter was the most common season $(n=486 ; 30.6 \%)$ and January $(n=182 ; 11.5 \%)$ was the most common month for medico-legal admissions. The majority of the patients $(n=551 ; 34.75 \%)$ presented to our emergency between 18-24 hours. 947 cases (59.7\%) had health risks at the time of presentation.
\end{abstract}

Conclusion: Developing effective preventive strategies is essential to prevent child and adolescent injuries.

Key Words: Adolescent, Child, Medico-legal, Pediatric emergency

\section{ÖZET}

Amaç: Pediatrik acil servislerde adli olgular önemli bir halk sağlığı problemidir. Adli olguların pediatrik fiziksel sakatlık ve Ölümün önde gelen nedenlerinden olduğu düşünülmektedir. Pediatrik acil servisimize adli olgu olarak başvuran hastaların demografik özelliklerini incelemeyi amaçladık.

Gereç ve Yöntemler: 2 yıllık bir çalışma periyodunda acil servisimize başvuran ve adli olgu olarak tedavi edilen toplam 1856 kişi çalışmaya alındı. Hasta bilgileri hastane kayıtlarından elde edilmiştir ve acil servis doktorları tarafından analiz edilmiştir.

Bulgular: Çalışmaya 671 erkek (\%42.3) ve 915 kız (\%57.7) dâhil edildi. Hastaların çoğunluğu 11- 14 yaş grubundaydı ( $n=397 ;$ \%25.0). Illaç alımı en sık başvuru nedeniydi $(n=827 ; \% 52.1)$. Adli olgu başvurularında kış mevsimi en sık başvuru mevsimi ( $n=486$; \%30.6), Ocak ayı en sık başvuru ayıydı ( $n=182 ; \% 11.5)$. Hastaların çoğunluğu 18-24 saatleri arasında başvurmuştu ( $n=551$; \%34.75). 947 olgunun (\%59.7) başvuru anında hayati riski vardı.

Sonuç: Çocuk ve adölesan yaralanmalarını önlemede efektif önleyici stratejilerin geliştirilmesi gereklidir.

Anahtar Sözcükler: Adölesan, Çocuk, Adli olgu, Pediatrik acil

\section{INTRODUCTION}

Unintentional childhood injuries are important issues that affect public health problems all over the world. They are considered major causes of short- and long-term disabilities. They are also considered leading causes of death in children and adolescents (1). Injury is defined as any tissue damage caused by 
exposure to any physical or chemical agent (2). Any external condition that intentionally or accidentally affects the physical or mental health of a patient and leads to any health risk or death is considered a medico-legal condition (3).

There are very few population-based investigations that focus on the incidence of injuries among children and adolescents (4-6). These studies have concluded that the age, sex, socioeconomic status, and geographic location are the major determinants of the incidence of injuries.

Unintentional childhood injuries, regardless of their outcome, can lead to serious and important sequelae such as limitation of activity, time in bed, and absence from the school (4). In addition to that, it can lead to serious work and financial problems, anxiety and decreased overall quality of family life $(7,8)$.

The aim of our present study was to evaluate the demographic aspects of pediatric medico-legal patients and to analyse the variables that affect their presentation to the pediatric emergency service.

\section{MATERIALS and METHODS}

This cross-sectional descriptive study was conducted at the emergency service of Ankara Pediatric Hematology and Oncology Research and Training Hospital between January 2012 and December 2013. Our data were collected from the medico-legal reports in our pediatric emergency service and were evaluated retrospectively by medical doctors.

The medico-legal form includes the following information: gender and age of the patient, time, date, month and season of admission, medical diagnosis and the possibility of health risks. Those who had multiple trauma, multiple organ dysfunction and those who needed further examination and treatment or hospitalisation were considered to have possible health risks.

The study was approved by the Medical Ethics Committee of Ankara Pediatric Hematology and Oncology Research and Training Hospital.
Statistical analyses were performed by using SPSS version 18.0. Categorical variables were shown as frequencies.

\section{RESULTS}

A total of 1586 children presented to our pediatric emergency service with medico-legal injuries, representing 6.75 per 1000 of the total number of children (234.656) seen within the period of this study. 671 males (42.3\%) and 915 females (57.7\%) were included in this study. Mean age \pm SD was 10,52 5.94 for male patients and $7.61 \pm 5.86$ for the females. The major age group was $11-14$ years $(n=397 ; 25 \%)$ followed by the $15-18$ years age group ( $n=365 ; 23 \%)$. Demographic properties of the service users are presented in Table I. Winter was the most common season $(n=486 ; 30.6 \%)$ and January $(n=182 ; 11.5 \%)$ was the most common month for medico-legal presentations. The majority of patients $(n=551 ; 34.75 \%)$ presented to our emergency service between 18-24 hours. 947 cases (59.7\%) had health risks at the time of presentation. The presentation time of the medico-legal patients is depicted in Table II. Drug intake was the major complaint ( $n=827 ; 52.1 \%$ ) of our patients while other complaints are presented in Table III.

\section{DISCUSSION}

In our present study, we evaluated the incidence of medicolegal cases of children and adolescents, their demographic features and factors affecting their presentation to our emergency service.

During the study period, we estimated that 234.656 patients presented to our pediatric emergency service. Only 1586 (6.75 per 1000 ) were treated as medico-legal cases. In our present study, the rates of medico-legal cases were different from those reported in prior studies. Sever et al. (3) and Yücel et al. (9) reported rates of medico-legal cases as $2.3 \%$ and $7.4 \%$ respectively and the difference in rates may be a reflection of multiple factors that affect presentations to emergency services (10). There is evidence that younger parents, lower education

Table I: Demographic properties of the patients.

\begin{tabular}{|c|c|c|c|c|c|c|}
\hline \multirow{2}{*}{ Age group } & \multicolumn{2}{|c|}{ Males } & \multicolumn{2}{|c|}{ Females } & \multicolumn{2}{|c|}{ Total } \\
\hline & Frequency & Percent & Frequency & Percent & Frequency & Percent \\
\hline $0-2$ years & 169 & 10.66 & 140 & 8.84 & 309 & 19.50 \\
\hline 3-5 years & 175 & 11.06 & 143 & 9.05 & 318 & 20.10 \\
\hline $6-10$ years & 84 & 5.32 & 101 & 6.38 & 185 & 11.70 \\
\hline $11-14$ years & 135 & 8.50 & 262 & 16.50 & 397 & 25.00 \\
\hline $15-18$ years & 103 & 6.50 & 262 & 16.50 & 365 & 23.00 \\
\hline Missing & 5 & 0.26 & 7 & 0.44 & 12 & 0.70 \\
\hline Total & 671 & 42.30 & 915 & 57.67 & 1586 & 100.00 \\
\hline
\end{tabular}


and lower- income of families are some factors that increase the injury risk in pediatric patients (5).

As shown in Table III, the majority of our medico-legal patients were medically treated, non traumatic cases, and drug intake was the most common complaint ( $n=827$; $52.1 \%$ ) of our patients. Drug intake was accidental in infants and young children and was due to suicidal behaviour in adolescents. These results are not comparable with those of prior studies that reported higher rates of traumatic rather than medical inquiries presenting to the pediatric emergency service and treated as medico-legal cases $(3,9)$. The fact that explains the lower rate of our traumatic patients than those reported by the previous studies is that our emergency service accepted only medical cases while the traumatic patients were directly referred to the trauma emergency services at other hospitals in Ankara. Traumatic cases included in our study were misdirected to our service and they were first stabilised in our pediatric emergency service then referred to trauma services at other hospitals.

$52,1 \%$ of our medico-legal patients applied to pediatric emergency service as a result of drug intake. In consistent with

Table II: Presentation time of the medico-legal patients.

\begin{tabular}{|c|c|c|c|}
\hline Variable & Time & Frequency & Percent \\
\hline \multirow{6}{*}{ Season } & Winter & 486 & 30.6 \\
\hline & Spring & 423 & 26.7 \\
\hline & Summer & 317 & 20.0 \\
\hline & Autumn & 359 & 22.6 \\
\hline & Missing cases & 1 & 0.1 \\
\hline & Total & 1586 & 100.0 \\
\hline \multirow{14}{*}{ Month } & January & 182 & 11.5 \\
\hline & February & 153 & 9.6 \\
\hline & March & 137 & 8.6 \\
\hline & April & 128 & 8.1 \\
\hline & May & 159 & 10.0 \\
\hline & June & 98 & 6.2 \\
\hline & July & 109 & 6.9 \\
\hline & August & 110 & 6.9 \\
\hline & September & 131 & 8.3 \\
\hline & October & 99 & 6.2 \\
\hline & November & 129 & 8.1 \\
\hline & December & 150 & 9.5 \\
\hline & Missing cases & 1 & 0.1 \\
\hline & Total & 1586 & 100.0 \\
\hline \multirow{6}{*}{$\begin{array}{l}\text { Time period } \\
\text { (Hour) }\end{array}$} & 06-12 & 293 & 18.48 \\
\hline & $12-18$ & 484 & 30.50 \\
\hline & $18-24$ & 551 & 34.75 \\
\hline & $24-06$ & 229 & 14.44 \\
\hline & Missing cases & 29 & 1.83 \\
\hline & Total & 1586 & 100.0 \\
\hline
\end{tabular}

a previous study, Turla et al. (11) found that drug poisoning was the prominent complaint of medico-legal cases aged between 0-18 years. The American Association of Poison Control Center reported that in 2003, $65.8 \%$ of drug poisoning cases were between 0-19 age pediatric cases (12). Sever et al. (3) and Yucel et al. (9) found that drug poisoning was the major reason of non traumatic medico-legal cases admitted to pediatric emergency service.

Evening hours between 18-24 hours was the most frequent period of our medico-legal presentation ( $n=551 ; 34,75 \%)$. This is consistent with the past population-based studies of pediatric emergency applications that deduced that the most frequent time period for pediatric emergency service applications especially for medico-legal cases and intoxications were between 16-24 hours (9,13-14).

Unlike the previous studies $(3,9,11)$, our patients frequently presented in Winter $(n=486 ; 30.6 \%)$, and January $(n=182$; $11.5 \%$ ) was the most frequent month for presentations. The previous studies concluded that summer was the most frequent period of the year for pediatric medico-legal presentations peaked during June to August. The result was due to summer holidays of schools where children had longer outdoor playing time than any other season. This in turn, increased the possibility of incidental trauma and injuries. Our data revealed that a large number of children were injured as a result of drug consumption at home during the winter season when parents preferred their children to stay at home rather than playing outside.

The incidence of pediatric medico-legal events is high and may result in transient or permanent sequelae that lead to important

Table III: Chief complaints of the patients.

\begin{tabular}{|l|r|r|}
\hline Chief complaint & Frequency & Percent \\
\hline Drug intake & 827 & 52.1 \\
\hline Carbon monoxide intoxication & 356 & 22.4 \\
\hline Toxic substance consumption & 104 & 6.6 \\
\hline Corrosive substance oral intake & 79 & 5.0 \\
\hline Food poisoning & 46 & 2.9 \\
\hline Alcohol consumption & 54 & 3.4 \\
\hline Inhaled gas exposure & 22 & 1.4 \\
\hline Trauma & 21 & 1.3 \\
\hline Electric shock & 20 & 1.3 \\
\hline Arrest & 12 & 0.8 \\
\hline Loss of consciousness & 10 & 0.6 \\
\hline Narcotics & 9 & 0.6 \\
\hline Swallowing foreign substance & 6 & 0.4 \\
\hline Bite & 3 & 0.2 \\
\hline Abandoned infant & 2 & 0.1 \\
\hline Drowning & 2 & 0.1 \\
\hline Missing cases & 13 & 0.8 \\
\hline Total & 1586 & 100.0 \\
\hline
\end{tabular}


health risk or death. The best part of our study group (59.7\%) had health risks at the time of admission, 12 of them died shortly just after admission to emergency service. The consequences of the other patients who had health risks were not will known. This was due to the fact that our present study is a retrospective study and depending upon data collected from hospital records that were uncompleted. Data about patients hospitalised or send to another hospitals for further examination and treatment were not enough for any statistical analysis. The investigation of these limitations will be important directions and guides for future researches. Further studies in our population should be conducted to develop effective preventive strategies fort the medico-legal issues.

\section{REFERENCES}

1. World Health Organisation. World Report on Child Injury Prevention. Accessed: 12 September 2015. Available from: http://www.who. int/ violence_injury_ prevention / child/injury/world_report/report/ en/

2. Judy K. Unintentional injuries in pediatrics. Pediatr Rev 2011;32:431-38.

3. Sever M, Saz EU, Koşargelir M. An evaluation of the pediatric medico-legal admissions to a tertiary hospital emergency department. Turk J Trauma \& Emergency Surgery 2010;16: 260-67.

4. Rivara FP, Calonge N, Thomson RS. Population-based study of unintentional injury incidence and impact during childhood. Am Public Health 1989;79: 990-4.
5. Petridou E, Anastasiou A, Katsiardanis K, Dessypris K, Spyridopoulos T, Trichopoulos D. A prospective population based study of childhood injuries: The Velestino town study. European Journal of Public Health 2005;15:9-14.

6. Pieri R, Minotti D, Gentili L, Negosanti I, Ricci L, Bedei G, et al. Injuries in childhood: A study on emergency department admissions of pediatric population in an Emilia-Romagna USL. Pediatr Med Chir 1992;14:293-96.

7. Gofin R, Adler B, Hass T. Incidence and impact of childhood and adolescent injuries: A population-based study. J Trauma 1999;47:15-21.

8. Osberg JS, Kahn P, Rowe K, Brooke MM. Pediatric trauma: Impact on work and family finances. Pediatrics 1996;98:890-97.

9. Yücel AB, Sütoluk Z, Yılmaz LH, Akbaba M, Aytaç N. Evaluation of the patients having visited Pediatric Emergency Service in the Faculty of Medicine of Cukurova University and recorded as medicolegal cases in 2004. Adli Tıp Bülteni 2005;10:90-5.

10. Streatfield PK, Khan WA, Bhuiya A, Hanifi SM, Alam N, Diboulo E, et al. Mortality from external causes in Africa and Asia: Evidence from INDEPTH Health and Demographic Surveillance System Sites. Glob Health Action 2014:7;25366.

11. Turla A, Aydın B. Evaluation of the judicial cases that have been admitted to Ondokuz Mayıs University Medical Faculty. Adli Tıp Bülteni 2007;12:106-11.

12. Watson WA, Litovitz TL, Klein-Schwartz W, Rodgers GC, Youness J, Reid N, et al. 2003 annual report of the American Association of poison Control Centers Toxic Exposure Surveillance System. Am J Emerg Med 2004;22:335-404.

13. Kurugöl Z, Mutlubaş F, Koturoğlu G, Vardar F, Özkınay F, Özkınay C, et al. Çocukluk çağında kazalar ve zehirlenmeler. Ege Pediatri Bülteni 2001;8:79-82.

14. Bertan M, Güler Ç. Halk Sağlığı Temel Bilgiler. Ankara: Güneş Kitabevi, 1997:462-72. 